ISSN:

Print - $2277-078 \mathrm{X}$

Online - $2315-747 \mathrm{X}$

(c) FUNAAB 2016

Joumal of

\title{
EFFECT OF RURAL-URBAN MIGRATION OF YOUTHS ON RURAL DEVELOPMENT IN OGBOMOSO SOUTH LOCAL GOVERN MENT AREA, OYO STATE. NIGERIA.
}

\author{
A. O. OKETAYO AND Y. L. OLALEYE \\ Department of Social Work, University of Ibadan, Ibadan, Oyo State, Nigeria.
}

Comesponding Author: yemisi1957@yahoo.co.u Tel.: +2348037139098

\begin{abstract}
ABST RACT
The study examined the effect of rural-urban migration of youth on rural development in Ogbomoso South Local Government Area of Oyo State. Rural-urban migration is a phenomenon that most developing nations of the world are experiencing due to the gross neglect of the rural areas. In Nigeria, the issue of rural-urban migration is quite alarming owing to the discriminatory centralization of facilities in the urban areas as well as widening income gap between the urban and rural areas. This study adopted a descriptive survey research design while purposive sampling technique was used in selecting 300 from Ogbomoso south LGAs. The data collected was tested by using Pearson product moment correlation and ANOVA. The study established that self-help project had significant relationship with youth out-migration $\left(r=.351^{*}, N=300, P<.05\right)$, community economy also had significant relationship with out-migration $\left(r=.277^{*}, N=300, P<.05\right)$, care for elderly had negative significant relationship with out-migration $\left(r=-.182^{\star}, N=300, P<.05\right)$ and cultural practices also had significant relationship with out-migration $\left(r=.198^{*}, N=300, P<.05\right)$. The study recommended that; government should decentralize its developmental projects and programmes in order to accommodate the rural areas. Government should make agriculture attractive for rural dwellers so that they could see it as a profitable occupation and there should be economic incentives to promote adaptation of indigenous skills and technologies in the rural areas.
\end{abstract}

Keywords: Rural-urban migration is a phenomenon that most developing nations of the world

\section{INTRODUCTION}

Development as a multi-dimensional concept could be generally referred to as the transformation of areas with rural character into towns, and towns into cities. It is, in other words the growth of towns from their hitherto statuses of rural settings. As noted by Abass (2012) that in an ideal and orthodox setting, such processes of development through urbanization should usually come along with industrialization through the es- tablishment of factories and the expansion of employment opportunities, which ideally should however produce a thriving industrial town.

Additionally, the development of one part of the system may be detrimental to the development of other parts, giving rise to conflicting objectives (trade-offs) and conflicts. Consequently, measuring development, i.e. determining whether and to what extent a 


\section{A. O. OKETAYO AND Y. L. OLALEYE}

system is developing, is an intrinsically multidimensional exercise. In Nigeria and many developing countries, there has been rapid growth of cities at the detriment of the rural areas. The rural population is gradually shrinking, while the urban population is blooming. Ward and Brown (2009) found that Nigeria is a typical example of a country, where there had been a tremendous expansion of urban areas consequent to the rapid rural migration.

The rural areas in Nigeria are endowed with both human and materials resources, unfortunately, these potentials are yet to be harnessed and used for rural development. According to Iosifides \& King (1999), useful natural resources, which can be harnessed for socio-economic development, abound in Nigeria particularly in the rural areas. Therefore, the migration of youths from rural areas to cities in search of better life, is taking away the potential youths who are capable of developing the rural areas.

Rural development is a philosophical concept that promote lifelong learning and community building activities while emphasizing an expanded role for public education and other human service organizations in meeting the needs of communities and improving the quality of life for all. The strategy of rural development in most countries is undergoing a change of emphasis from mere agricultural development to the development and total mobilization of the potential human and material resources of the area for improvement of living condition. The aim is for the rural population to achieve a more equitable access to the available resources. With emphasis shifting to a more comprehensive type of development, community projects based on self-help and community assistance have accordingly di- versified (O laleye, 2008)

The age between 15 and 24 is a crucial development life phase, during which some major life tasks are expected to be accomplished or at least begun. Youths constitute the most significant part of the world population. They are the most active, diligent, creative, contributive, innovative and energetic people. Young people are expected to establish a sense of personal identity and become progressively more independent of parents. They move from school into the workforce, either directly or via further education or training. Y outh development and empowerment are vital stages in life for building the human capital that allows young people to avoid poverty and possibly lead to a more fulfilling life. (Olaleye, 2012).

Migration has also been identified as a survival strategy utilized by the poor, especially the rural dwellers. The assessment of the effects of migration on rural areas has remained relevant since migration acts as a catalyst in the transformation process of not only the destiny of individual migrants but also the conditions of family members left behind, local communities, and the wider sending regions (Nyagba, 2009). O ne significant source of development for the rural populace as a result of this increasing drift towards the cities is remittances.

The effects of rural-urban migration in the rural places of origin of migrants may be manifest in two ways. First, the rural-urban migrants send remittances to their relatives in the rural areas and these remittancereceiving households use the remittances for various purposes. Secondly, these ruralurban migrants execute various rural developmental projects in their rural areas of origin. In Nigeria, most migrants coming from 
a particular rural community to live in an urban area usually form rural community associations in the urban area. These community associations in the urban areas articulate, from time to time, the developmental needs of their rural communities of origin and contribute resources to execute projects such as road construction and the award of educational scholarships to students in the rural areas (Ugwuanyi and Chukwuemeka, 2013)..

There are shades of opinions as to who could be regarded as a youth. It is certain that economic condition, religious dogma, cultural norms, environment, political imperative and other needs of the society determine the age limits for qualification as a youth (Bammeke, 2002). According to National Youth D evelopment Programme and Implementation Strategies of Nigeria (2007), any person aged between 12 and 35 years who is passing through mental and physical development process in preparation to face the challenges of adulthood is regarded as a youth (Adebowale, Atte and Ayeni, 2012). This definition tends to perceive the youth as preparatory stage of life when one leaves one period and enters into another period.

The large number of able-bodied men and women moving to the cities is at an alarming rate. The intention of the movement varies; some migrate to the urban centers in search of job, while others migrate to enjoy basic amenities that are lacking in the rural areas. Unfortunately, there is no expansion or improvement on the basic amenities in the cities to meet with the increasing demand of the growing population. Thus, most of the migrants end up in slums, where they compete with each other for survival. As a result, the overcrowded cities suffer the consequences of overstretched few facilities. The migration also takes away able-bodied young men and women from the rural areas to urban centers, thereby making the rural areas to lose the manpower necessary for agriculture and rural development(Eliss \& Harris, 2004).

Migration is a selective process affecting individuals or families with certain economic, social, educational and demographic characteristics (Wang, Ratoola and Xiangming, 2010). People migrate based on the prevailing conditions and the reasons for it vary from one person to another depending on the situation that brought about the decision. Rural - urban migration was formerly regarded as favourable in economic development (Carling, 2005). Today, it has become one of the most embarrassing problems in the Nigerian development experience. People migrate from the rural to urban areas as a reaction to socio-economic issues such as inferior social and economic facilities such as health care, educational opportunities, transportation system, electricity, pipe borne water, housing conditions amongst others, in the rural areas compared to those in the urban areas, and degrading view of rural areas and its inhabitants ( Gazdar, 2003).

Nigeria's economy was founded on agriculture. Before, the oil boom agricultural production was concentrated in the rural areas where farmers had fertile farmland and human resources in abundance. The income obtained from the sale of farm product was sufficient to cater for farm families and for foreign exchange. The discovery of oil and its subsequent exploration and exportation brought a setback to Nigeria's agriculture because, the government shifted attention from the agricultural sector to oil industry which encouraged the drifting away of young 


\section{A. O. OKETAYO AND Y.L. OLALEYE}

able bodies from rural to urban areas (Badru, 2004).

Migration of young adults from the rural areas also placed a greater burden on the farmers. For farmers to cover the same area of land as when he had extra assistance, he must work much longer hours thus depriving him of some time for leisure or participation in various social activities. Ruralurban migration has a positive impact on urban growth and social development. It creates employment opportunities, enhance provision of educational facilities and transportation infrastructure for the migrants (Adebowale, Atte and Ayeni, 2012). Also, the rural-urban migration has led to degeneration of indigenous skills such as mat making, pot making, bone setting, tradomedicine among others. Unfortunately, the allure of urban life has pushed those with these skills to the cities (Chigbu, 2012). In most cases, such skills are abandoned to other blue-collar jobs.

The problem with the increases in migrants into urban settlements in Nigeria are increasing day by day. Thus, rural-urban migration poses a lot of problem to the destination areas and as such immigrants becomes disappointed on getting to the urban areas as they are left with poor housing, overcrowding, high cost of living, traffic congestion. Population mobility has brought about great changes in towns in developing countries, the effects being extremely diverse and the problems numerous (Tan, 2010). Severe strains have been placed on the provision of other social amenities such as health, educational and transportation services as a result of the rapid rate of population growth. The out-migration can also cause the drain of skills and the loss of innovative community members from rural areas. Rural dwellers are less vocal, characterized by a culture of poverty, as most people live barely above subsistence level (Laah, Abba, Ishaya and Gana, 2013). This usually drains the brain from the rural areas that are supposed to initiate progressive ideas for the development of the rural areas.

The rural sector of Nigeria is very vital to the socio-economic development of the nation. According to Nyagba (2009) the most important sector of the population is the rural areas. This is because the rural sector is the major source of capital formation for the country and a principal market for domestic and raw materials for industrial processes (Ugwuanyi and Chukwuemeka, 2013). Rural area dwellers have been found to engage in primary economic activities that form the foundation for the country's economic development (Abbah, 2010)

The inequality between the rural and urban areas in the provision of basic facilities is another major factor responsible for rural urban migration among the youths in Nigeria. Most of the rural areas in Nigeria lack basic amenities such as electricity, water, good roads, clinics housing and good employment housing. These usually push the youths to migrate to the urban areas in order to access the aforementioned. Other challenges faced by the youths in rural areas are, unemployment and low standard of living. All these factors encouraged the migration of youths from rural to urban centers (Adewale, 2005).

The high level of migration among the youths from rural to urban centers in Nigeria has affected food production, thereby causing the problem of food insecurity. The youths who are the productive group in rural areas migrates to urban centers leaving be- 
hind the aged and children who are weak and cannot engage in farm work (Oke, 2012). Thus, agriculture and rural development suffer set back as a result of the youths migration. In most rural areas, the impact of rural-urban migration has led to a rapid deterioration of the rural economy leading to chronic poverty and food insecurity. Rural areas in developing countries are deprived of the basic needs of life such as housing, medical care, postal communication, education, transport etc. This arises mainly due to excessive drain of youth from the rural populace thus leaving only the older and aged members to constitute the labor force of the rural area. In the light of this, the study examine the effect of migration of youths on rural development.

\section{Research Hypotheses}

$\mathrm{H}_{01}$ There will be no significant relationship between self-help project and youth out-migration

$\mathrm{H}_{\mathrm{O} 2}$ There is no significant relationship between community economy and youth out-migration

$\mathrm{H}_{03} \quad$ There is no significant relationship between care of elderly and youth outmigration

$\mathrm{H}_{04} \quad$ There is no significant relationship between cultural practices and youth outmigration

$\mathrm{H}_{\mathrm{O} 5}$ There is no significant influence of self -help project, community economy and cultural practices on youth out-migration

\section{Objective of the Study}

The main objective of this study is to examine effect of migration of youths on rural development; to assess the effects of out migration on rural development of Ogbomoso South Local Government Area; to identify the extent to which youth migration affect the people of Ogbomoso South Local
Government and to investigate the causes of youth migration to urban areas and to determine the implications of rural-urban migration on rural development.

\section{METHODOLOGY}

\section{Research Design}

The research design adopted for the study is the descriptive survey research design as it facilitates easy collection of information about the research problem.

\section{Population of the Study}

The target population for the study comprised both male and female youths from 10 political Wards that comprise Ogbomoso South Local Government Area namely; OkeOla, Alubata, A toba, Alapata, Ijeru, Ibapon, Olokoto, Low Cost, Olode and Idi Igba.

\section{Sampling Technique and Sample Size}

Simple random sampling technique was used for the study to select respondents (youths) from each of the ward, 30 youths rural urban migrants were used for the study while 10 wards in O gbomoso South Local Government Area which made the total respondents used for the study to become three hundred.

\section{Research Instrument}

The instrument used for the study was a self constructed questionnaire tagged Effect of Migration of Youth on Rural Development Questionnaire (EMYRDQ). The questionnaire was divided into six sections. Section A - F; 4 likert scale ranging from "Strongly Agree" (1) to "Strongly Disagree" ( 4) was used for section B-F. Section A: contains the demographic variables of the respondents, Section B: Scale measuring effect of youth out-migration on self - help project, Section C: Scale measuring effect of youth out-migration on community economy, Section D: Scale measuring effect of youth out- 
migration on care of elderly, Section E: a sample size of 50 respondents in OgoScale measuring effect of youth out- Oluwa Local Government Area which is migration on socio-cultural practices

Section F: Scale measuring causes of youth out-migration

\section{Validity and Reliability of the Instru- ment}

The face and content validity of the instrument was ascertained through consultation with experts in the field of community social work and social welfare for their suggestion. A pilot study was carried out using outside the wards of study. This was done within an interval of two weeks. A coefficient of $r=0.63$ was obtained. This confirmed the accuracy of the instrument

\section{Method of Data Analysis}

Data collected through the questionnaire were analyzed using Person Product moment correlation and Regression (ANOVA) for the joint and relative effects of the independent variable.

\section{RESULTS AND DISCUSSIONS}

Table 1: Pearson Product Movement Correlation (PPMC) Showing the Relationship between Youth Out-migration and Self-Help Project

\begin{tabular}{lcccccc}
\hline Variable & Mean & Std. & N & R & P & $\begin{array}{l}\text { Remark / } \\
\text { Decision }\end{array}$ \\
\hline Self-Help Project & 11.7000 & 2.9686 & & & & \\
& & & 300 & $.351^{*}$ & .000 & Sig. \\
Y outh Out-migration & 7.7633 & 1.8050 & & & & \\
\hline
\end{tabular}

* Sig. at .05

It is shown in Table 1 that there was a positive significant relationship between selfhelp project and youth out-migration ( $\mathrm{r}$ $=.351 *, \mathrm{~N}=300, \mathrm{P}<.05)$. The research hypothesis is rejected which states that, there is no significant relationship between self-help project and youth out-migration. This finding agrees with Abah (2010) that rural-urban migration has moved ablebodied young adult people from the rural areas to urban centres, thereby making the rural areas to lost the manpower necessary for Agriculture and rural development. Rural-urban migration has accounted for the underdevelopment of rural areas vis-à-vis: loss of local man-power; fall in agricultural productivity; degeneration of indigenous skills; loss of culture and accounting for dull village life.

It is shown in the above table 2 that there was a positive significant relationship between community economy and youth outmigration $(r=.277 *, N=300, P<.05)$. Research hypothesis which indicates that there was no significant relationship between community economy and youth out-migration is rejected. The finding support the study of Ugwuanyi and Chukwuemeka (2013) that rural sector is the major source of capital formation for the domestic and raw materials for industrial processes The result also 
EFFECT OF RURAL-URBAN MIG RATION OF YOUTHS ON RURAL DEVELOPMENT IN...

buttress by the findings of Chigbu, (2012) industries and development options if propthat the rural-urban migration has led to degeneration of indigenous skills such as mat making, pot making, bone setting, trado -medicine among others. These skills as noted by the interviewees could act as local erly harnessed. Unfortunately, the allure of urban life has pushed those with these skills to the cities. In most cases, such skills are abandoned to other blue-collar jobs.

Table 2: Pearson Product Movement Comelation(PPMC) Showing the Relationship between Community Economy and Youth 0 ut-migration

\begin{tabular}{lllllll}
\hline Variable & Mean & Std. & N & R & P & $\begin{array}{l}\text { Remark/ } \\
\text { D ecision }\end{array}$ \\
\hline Community Economy & 16.4467 & 1.5038 & & & & \\
& & & 300 & $.277 *$ & .000 & Sig. \\
Youth Outmigration & 7.7633 & 1.8050 & & & & \\
\hline
\end{tabular}

* Sig. at .05

Table 3: Pearson Product Movement Correlation (PPMC) Showing The Relationship between Care of Elderly and Youth Outmigration

\begin{tabular}{lcccccc}
\hline Variable & Mean & Std. & N & R & P & $\begin{array}{l}\text { Remark / } \\
\text { Decision }\end{array}$ \\
\hline Care of Elderly & 11.5500 & 1.8490 & 300 & $-.182 *$ & .000 & Sig. \\
Youth Outmigration & 7.7633 & 1.8050 & & & & \\
\hline
\end{tabular}

* Sig. at .05

Table 3 shows in the above table 3 that are unable to work in the farm and the there was a negative significant relationship young adult will do as a result of their age. between care of elderly and youth out- This is in line with findings of Gazdar (2003) migration $(\mathrm{r}=-.182 *, \mathrm{~N}=300, \mathrm{P}<.05)$. and $\mathrm{Xu}$ and Chow (2011) who assert that The hypothesis which states that there was large number of younger people, able-bodied no significant relationship between care of men and women moving to the cities is at an elderly and out-migration is rejected. The alarming rate. The intention of the moveresult is supported by the findings of Ade- ment varies; some migrate to the urban cenbowale, Atte, and Ayeni (2012) who found ters in search of job, while others migrate to that rural- urban migration of young adult enjoy basic amenities that are lacking in the from rural areas placed a greater burden on rural areas which lead to under-development the farmers (elderly). Most elderly farmers of rural area. 
Table 4: Pearson Product Movement Comelation (PPMC) Showing The Relationship between Cultural Practices and Youth Out-migration

\begin{tabular}{ccccccc}
\hline Variable & Mean & Std. & $\mathrm{N}$ & $\mathrm{R}$ & $\mathrm{P}$ & $\begin{array}{l}\text { Remark ? } \\
\text { Decision }\end{array}$ \\
\hline Cultural Practices & 11.1067 & 2.2861 & 300 & $.198^{*}$ & .000 & Sig. \\
Youth Outmigration & 7.7633 & 1.8050 & & & & \\
\hline
\end{tabular}

* Sig. at .05

It is in the above table 4 that there was a Adewale, (2005) which asserts that culturally, positive significant relationship between rural-urban migration is closely related to the cultural practices and youth out-migration ( $\mathrm{r}$ violation of cultural heritage of the rural peo$\left.=.198^{*}, \mathrm{~N}=300, \mathrm{P}<.05\right)$. Research hy- ple. This owes to the fact the elderly and pothesis which indicates that there was no children left in the villages may not have the significant relationship between cultural zest and enthusiasm that keeps their cultural practices and youth out-migration is re- activities vibrant and thick. jected. This finding corroborate the study of

Table 5: Analysis of variance (ANOVA) showing Joint Effect Of Self-H elp Project, Community Economy, and Cultural Practices On Youth Out-migration

\begin{tabular}{|c|c|c|c|c|c|c|}
\hline \multirow{2}{*}{$\begin{array}{l}\mathrm{R} \\
.425\end{array}$} & \multicolumn{2}{|c|}{ R Square } & & \multirow{2}{*}{$\begin{array}{l}\text { Adjusted } \\
\text { R Square } \\
.169\end{array}$} & \multicolumn{2}{|c|}{ Std. Error of the Estimate } \\
\hline & .180 & & & & 1.645 & \\
\hline \multicolumn{7}{|c|}{ A $N O V A$} \\
\hline Model & $\begin{array}{l}\text { Sum of } \\
\text { Squares }\end{array}$ & DF & $\begin{array}{l}\text { Mean } \\
\text { Square }\end{array}$ & $\mathrm{F}$ & Sig. & Remark \\
\hline Regression & 175.839 & 4 & 43.960 & 16.243 & .000 & Sig. \\
\hline Residual & 798.358 & 295 & 2.706 & & & \\
\hline Total & 974.197 & 299 & & & & \\
\hline
\end{tabular}

Table 5 shows that the joint effect of the four independent variables (Self-Help Project, Community Economy, Care of Elderly and Cultural Practices) to the prediction of the dependent variable. i.e Youth O utmigration was significant. The table also shows a coefficient of multiple correlation $(\mathrm{R}=.425$ and a multiple $\mathrm{R}^{2}$ of .180 . This means that $18.0 \%$ of the variance was accounted for by four predictor variables when taken together. The significance of the composite contribution was tested at $\mathrm{P}<.05$. The table also shows that the analysis of variance (ANOVA) for the regression yielded a Fratio of 16.243 (significant at 0.05 level). This implies that the joint contribution of the independent variables to the dependent variable was significant and that other variables not included in this model may have accounted for the remaining variance. 
The finding is corroborated with the study of Laah, et al, (2013) that factors influencing the decision to migrate are varied and complex for example social factor; which can be desire of migrants to break away from traditional constraints of social organizations; physical factors inform of reduction of mortality rate and concomitant growth. Rural dwellers are less vocal, characterized by a culture of poverty, as most people live barely above subsistence level. The result is also supported the findings of Chigbu
(2012) that who stated that migration occurs as a response to economic development as well as social, cultural, environmental and political factors and effects on areas of origin as destination. The large number of ablebodied men and women moving to the cities is at an alarming rate. The intention of the movement varies; some migrate to the urban centers in search of job, while others migrate to enjoy basic amenities that are lacking in the rural areas.

\section{Table 6: Relative Contribution of the Independent Variables (Self-H elp Project, Community Economy, And Cultural Practices) On Youth Outmigration}

\begin{tabular}{llllll}
\hline Model & $\begin{array}{l}\text { Unstandardized Co- } \\
\text { efficient } \\
\text { B }\end{array}$ & Std. Error & Stand. Coefficient & T & Sig. \\
& & & & & \\
\hline (Constant) & 4.870 & 1.350 & & 3.608 & .000 \\
Self-Help Project & .147 & .040 & .242 & 3.666 & .000 \\
Community Econ- & .123 & .078 & .102 & .605 & .109 \\
omy & .124 & .045 & .158 & 2.746 & .006 \\
Cultural Practices & & & & & \\
\hline
\end{tabular}

Table 6 reveals the relative contribution of the three independent variables to the dependent variable, expressed as beta weights, viz:

- Self-Help Project, $(\beta=.242, \mathrm{P}$ $>.05$ ), significant relationship existed;

- Community Economy, $(\beta=.102, P$ $>$.05), no significant relationship existed; and lastly

- Cultural Practices, $(\beta=.158, P$ $>.05$ ), significant relationship existed. This result indicated that selfhelp and cultural practices has high values in rural development of rural area.
This result is in line with the findings of Wang, Ratoola and Xiangming (2010) who assert that rural-urban migration are caused by some factors like unemployment, inadequate provision of social infrastructure in the rural communities. Younger people desire to migrate than the older people. Rural-urban out-migration can also cause the drain of skills and the loss of innovative community members from rural areas. This usually drains the brain from the rural areas that are supposed to initiate progressive ideas for the development of the rural areas.

\section{Policy Implications of the Study}

The study established that, the rural-urban migration has led to degeneration of indigenous skills. Most of skills in rural area are abandoned to other blue-collar jobs. Cultur- 


\section{A. O. OKETAYO AND Y. L. OLALEYE}

ally, rural-urban migration is closely related to the vitiation of cultural heritage of the rural people. The elderly and children left in the villages may not have the zest and enthusiasm that keeps their cultural activities vibrant and thick. The consequences of depopulation of rural areas are ; reduction in rural agricultural produce, reduction in Gross D omestic Production (GDP) of the nation, decline in the standard of living, inaccessibility, remoteness, underdevelopment, poverty, ignorance, hunger and starvation of the rural inhabitants.

Youth migration also leads to overpopulation of urban centres. Rural-urban migration effects on the urban centers includes overpopulation, insufficient physical and social infrastructural amenities. Ruralurban migration brings pressure on urban housing and the environment as migrants arrive from rural areas they live on the streets and makeshift sub-standard accommodation before establishing themselves. Rural-urban migration leads to overpopulation of the urban centres thus encouraging and raising the rate of crime in the society. Rural-urban migration also slows down the pace of development of the rural areas.

\section{CONCLUSION}

Based on the finding of this study, it was established that migration from rural to urban areas leads to a reduction in the number of rural populace. This has a negative effect on rural agricultural output and thus hinders the pace of development in the rural areas. The youths migrate from the villages leaving behind the feeble old men, women and children to labour on the farm since farming is their major occupation. This has led to a reduction in agricultural produce with its consequential effect on the gross domestic product of the nation, low-

ered fund for development, income and standard of living of rural inhabitants, under development, and total desertion of the rural areas.

\section{RECOMMEN DATIONS}

This findings revealed that younger people desire to migrate than the older people with the majority of this figures being male migrants which lead to underdevelopment of rural area. Against the backdrop of these negative consequences of rural-urban migration to the underdevelopment of rural areas, the following recommendations were made to curb its prevalence and ensure the development of the Nigeria rural areas:

1. Government should encourage the drift of people to rural areas by making available such amenities that would encourage the stay of the migrants in their area.

2. Youth should be encouraged to form themselves into group / association which can be used to attract the attention of the Government or Nongovernmental organizations to establish small industries in the rural areas. This encouragement will enhance rapid rural development and bring the rural communities to the mainstream of national development.

3. Well meaning indigenes and corporate organizations operating in such environments should help provide social infrastructure that will keep the able bodied men and women in the rural areas.

4. Community-based development NGOs and stakeholders should provide the rural people with educational opportunities regarding how best to harness their indigenous skills.

5. The government should decentralize its development projects and programmes by 
concentrating more in the rural areas. Small scale industries should be established in the rural areas to check ruralurban migration.

6. There is need for government to constraint review its policies on development of rural areas.

G overnment should strengthening the process of rural renewal by greater thrust to schemes for reaching out quality facilities to the rural population.

\section{REFERENCES}

Abah, N. 2010. D evelopment Administration: A Multi-Disciplinary Approach. Enugu: John

Jacob Classic Publishers Adebowale, S., Atte, 0, \& Ayeni, 0 2012. Elderly Wellbeing in a Rural Community in North

Cenral Nigeria, Sub-Saharan Africa. Public HealthResearch 2(4): 92-101

Adewale, J. G. 2005. Socio - Economic Factors Associated with Urban-rural Migration in Nigeria: A case study of O yo State, Nigeria. department of Agricultural Economics and Extension, Faculty of Agricultural Sciences, Ladoke akintola University on Technology, Ogbomoso, Nigeria. pp. 1, 14-15.JHE-17-1-013-016-2005-21203Adewale-J-G.PD F.

Ayeni, B. 1998. Understanding and Planning of Cities: First Professor Nurudeen Alao's Lecture series in Urban Studies. Lagos: Lagos: Lagos State University. Pp 9-11.

Badru, F.A. 2004. Urbanization, Family and Social changes in Nigeria: 1950-1999. In Industrialization, Urbanization and Development in Nigeria 1950-1999. Edited by M.O.A. Adejugbe. Concept Publications
Ltd. Lagos.

Bammeke, F. 2002. Nigerian Youth, any Future? An unpublished paper, delivered at the National Youth Service Corps Week, Shomolu, Lagos

Carling J. 2005. Gender dimensions of international migration, Global Commission on International Migration, G eneva

Chigbu, U.E. 2012. Village Renewal as an Instrument of Rural D evelopment: Evidence from Weyarn, Germany. Community Development. Vol.43 (2) 209-224

Eliss, F. And Hamis, N. 2004. In New Agriculturist on-line: Reporting Agriculture for the 21st Century. 1st September 2004. p.1. http/ / www.new-ag.info/ 04-5/ dev.1.html.

Gazdar, H. 2003. 'A Review of Migration Issues in Pakistan', Refugee and Migratory Movements Research Unit, Bangladesh, DFID.

Gubert, F. 2002. 'D o Migrants Insure those who Stay Behind? Evidence from the Kayes Areas (Western Mali)', Oxford D evelopment Studies 30 (3)

Iosifides, T. and R. King, R. 1999. 'Sociospatial Dynamics and Exclusion of Three Immigrant $\mathrm{G}$ roups in the Athens Conurbation', in Baldwin-Edwards, M. and J. Arango, J. (eds.) Immigrants and the Informal Economy in Southern Europe. London: Frank Cass Publishers.

Laah, D.E., Abba, M., Ishaya, D.S. and Gana, j.n. 2013. The Mirage of Rural D evelopment in Nigeria. Jaumal of Sacial Saiences and PublicPdigy. Vol. 5, N0. 2, 148- 159.

Nyagba, S. 2009. "Review of Nigeria's Rural Development Policy for Sustainable D e- 
velopment". Paper presented at Business round table at Abuja. 9 - 11 July

Oke, M.0. 2012. Rapid Urban InMigration and Environmental Nuisance in Nigerian Cities : The case of street vending in Lagos City. Sustainable environmental planning and management in Nigeria; Urban and Regional Planning Department, Ladoke Akintola University, Ogbomoso, Nigeria

Olaleye, Y. L. 2008. Effect of Community Life Project on Socio-Economic D evelopment of the Urban-Rural D wellers in Isolo Local G overnment Area, Lagos State, Nigeria. Nigirian Jamal of Sacial Work Eduration, Vol. 7, 118-132

Olaleye, Y.L. 2012. Capacity-Building and its Effects on Reduction of Youth Unemployment in Nigeria. African Jaumal of His taical Saiences in Eduration, Vol. 8, No.1, 1718.

Tan, X. 2010. New Town Policy and Development in China. The Chinese Economy. Vol. 43, No. 3, 47-58
Ugwuanyi, B.I. and Chukwuemeka, E.0. 2013. Enhancing Rural Development in $\mathrm{Ni}$ geria. Periscoping the Impediments and Exploring Imperative Measures. Kumait

Chapter of Arabian Joumal of Business and Management Review Vol. 2, No. 7, 94-107

Ward, N. Brown, D.A 2009. "Placing the Rural in Regional D evelopment". Regional Studies. 43 (10): 1237-1244

Wang, L., Ratoola, K. \& Xiangming, C. 2010. Building for what and whom? New Town D evelopment as Planned Suburbanization in China and India, In: Suburbanization in Global Society. Rearch in Unban So adogy. Volume 10, 310- 345. Mark Clapson and Ray Hutchison (eds.). Emerald Group Publishing Limited.

Xu, Q., \& Chow, J. 2011. Exploring the Community-Based Service D elivery Model: Elderly Care in China. Intemational Social Work. 5, 374 D OI: 1177/ 0020872810396260

(Manuscript reecived 31st January, 2017; accepted 23rdJune, 2017 